\title{
A nutritional approach for the prevention of Post Weaning Syndrome in piglets
}

\author{
Annemarie DiRKZWAGER ${ }^{\mathrm{a}, \mathrm{b}}$, Bert VELDMAN $^{\mathrm{a}}$, Paul BIKKER $^{\mathrm{a} *}$ \\ ${ }^{\text {a }}$ Schothorst Feed Research, Meerkoetenweg 26, 8218 NA Lelystad, The Netherlands \\ b Present address: Animal Health Services, PO Box 9, 7400 AA Deventer, The Netherlands
}

(Received 10 May 2004; accepted 14 March 2005)

\begin{abstract}
In this article the disturbing steps in the process leading to the Post Weaning Syndrome (PWS) in piglets and its prevention is discussed from a nutritional point of view. The proposed sequence of disturbing steps in the gut is the following: when weaning occurs at three or four weeks of age, gut development to digest a 'vegetable' diet is immature and the normal gut morphology is disturbed by stress, infection, and a low feed intake. The impaired absorption and digestion increases the amount of undigested substrate and may cause explosive growth of bacteria. The colonization resistance is disturbed and for example Escherichia coli can proliferate. Practical measures regarding feeding strategy and feed composition to counteract these disturbing steps in this process leading towards PWS are discussed.
\end{abstract}

piglets / post-weaning / nutrition / gut development / Escherichia coli

Résumé - Une approche nutritionnelle pour la prévention du syndrome de post-sevrage chez le porcelet. Le syndrome du post-sevrage et sa prévention, chez le porcelet, sont discutés d'un point de vue nutritionnel dans cet article. Les troubles du tube digestif après le sevrage conduisant à ce syndrome sont les suivants : avec un sevrage à 3-4 semaines d'âge, le tube digestif est immature pour digérer les aliments végétaux, la morphologie intestinale est perturbée par le stress, les infections et le faible niveau d'ingestion alimentaire. La digestion et l'absorption des nutriments sont altérées, ce qui augmente la quantité de substrat indigestible et pourrait causer un développement bactérien explosif. La résistance à la colonisation est perturbée et les bactéries pathogènes, comme certaines souches d'Escherichia coli, peuvent proliférer. Des mesures pratiques concernant les stratégies alimentaires et la composition des aliments pour contrecarrer ces perturbations sont discutées.

porcelet / post-sevrage / nutrition / développement digestif / Escherichia coli

\footnotetext{
*Corresponding author: pbikker@schothorst.nl
} 


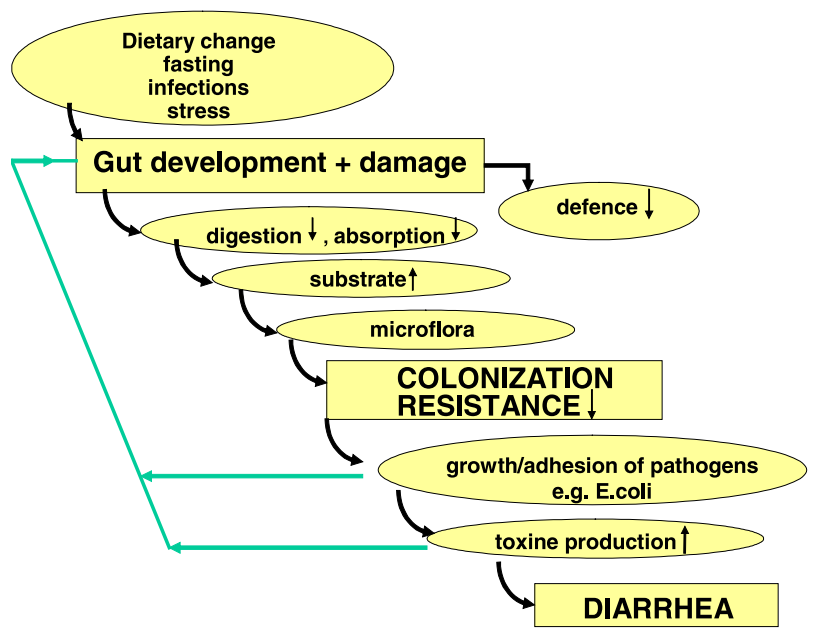

Figure 1. Processes leading to PWS.

\section{INTRODUCTION}

Gut infections immediately after weaning are still an important problem in pig husbandry. In earlier days PWS (Post Weaning Syndrome) was mainly regarded as a disease with Escherichia coli as the monocausal agent. Nowadays, PWS is regarded as a multi-factorial problem: management, feed composition, hygiene etc. play an important role in the expression of the disease $[13,14]$. An important aspect of the resistance in the gut against PWS is a diverse and stabile microflora, by which a so called tight 'colonization resistance' or 'competitive exclusion' is generated and growth and attachment of (pathogenic) bacteria is counteracted [15]. Newly weaned piglets may suffer from Post Weaning Syndrome because of the immature development of the gut and inadequate capacity to digest a 'vegetable' diet and because of gut damage caused by the weaning process. As a result, the colonization resistance is disturbed and E. coli can proliferate and attach to the enterocytes.

The disturbing steps in the process leading towards PWS, looked at from a nutritional point of view, are summarized in Figure 1 . In newly weaned piglets the gut can be damaged by the reduced feed intake immediately post weaning [2] and the increased susceptibility for infections like Rota virus. Moreover, weaning itself is a stressful moment. The villus height is reduced, crypt depth is increased, and the rate of mitoses is increased [16]. In addition, the development of the gut to digest a solid diet is inadequate $[4,7,12]$. These processes result in mal-digestion and mal-absorption and an increase of undigested feed in the ileum. This substrate induces an explosive growth of bacteria and a disturbance of the colonization resistance [6, 20]. Normally transient $E$. coli strains in the gut [13] can multiply and attach. The toxines produced by the different types of $E$. coli bacteria are responsible for the PWS symptoms.

Regarding the nature of the different disturbing steps, specific measures in feed composition and feeding strategy can be pointed out and will be discussed below. The description of the measures follows the different steps mentioned in Figure 1. It should be emphasized that a large number of measures have variable effects under practical conditions. The experimental evidence for the suggested mechanisms and effects is not yet complete. 


\section{PRACTICAL MEASURES}

\subsection{Improvement of gut development and prevention of gut damage at weaning}

Gut development for the digestion of 'vegetable' diets is immature at weaning. When weaning occurs at an age of three or four weeks, it takes 10-14 days before gut development is at a more mature level [4, 12]. In addition, the villus height is impaired after weaning because of the low feed intake, infection with e.g. Rota virus, stress etc. Voluntary feed and energy intake of piglets is often below maintenance during the first five days after weaning [10]. After this period, feed intake increases but gut development is still inadequate to digest a 'vegetable' diet. An important factor to prevent gut damage immediately after weaning and to diminish the overload with feed in an impaired gut is to stimulate feed intake the first four days after weaning and control feed allowance from 5-10 days after weaning. This implies that stimulation of feed intake before weaning is an important factor to prevent PWS. Following this line of thought, the measures to improve gut development and to prevent gut damage to be implemented in practical diets and husbandry management are mentioned below:

- Increase feed intake before weaning: supply a palatable diet to suckling piglets.

- Increase feed intake after weaning: use the same diets before and after weaning. The appearance of the diet influences feed intake. The use of soft pellets and wet diets have a positive effect on feed intake. Light management has an effect on feed intake; in dark periods the feed intake is low [2].

- Reduce gut damage by the addition of energy sources and growth factors for the enterocytes: e.g. butyrate, glutamine, nucleotides [11].

\subsection{Improvement of digestion and absorption in the gut, reduction of the amount of substrate}

The impaired digestive and absorptive function of the gut can be (partly) compensated by the provision of highly digestible diets or by the addition of supplements stimulating digestion. These measures diminish the amount of substrate and reduce the risk of bacterial growth. The following can support improvement of the digestibility:

- Addition of enzymes, e.g. glucanases and xylanase, but also proteases can be added to weaning diets [19].

- Technological treatment of the diets: the production of diets at higher temperature and pressure, e.g. pelleting and expanding increases the digestibility of carbohydrates and fat in the diet [21].

- Choice of raw materials and nutrients: there is a large variation in nutrient content and ileal and fecal digestibility of different raw materials. Piglet diets should be optimized with low levels of crude protein. Therefore well-digestible protein sources should be used (e.g. milk powder, fish meal). Diets should be optimized on low soluble NSP [6].

\subsection{Inhibition of the growth of pathogenic bacteria}

Growth of Enterobacteriaceae like E. coli is inhibited below $\mathrm{pH} 4$. Because of the fecal-oral recontamination, the stomach plays an important role in the infection cycle and an adequate function of the stomach with a low pH can decrease E. coli levels. Additives like organic acids and other measures with bacteriostatic or bacteriocidic activity are mentioned below:

- Addition of organic acids: in addition to a direct $\mathrm{pH}$ reducing effect, organic acids have a direct bactericidal activity by disturbing the bacterial metabolism. They may also improve stomach function, slow down stomach emptying rate, 
increase pancreatic enzyme production, and improve nutrient digestibility [18].

- Reduce the buffering capacity of the diet: a lower buffering capacity (mainly by a lower lime stone and crude protein content) improves the effects of stomach $\mathrm{HCl}$ production and the effectiveness of added dietary organic acids [18].

- Addition of coarse particles: coarse particles, especially those containing indigestible fiber improve stomach function [5].

- Essential oils: Essential oils may have bactericidal effects [22]. But there is still discussion about which essential oil is effective and what is the appropriate dosage.

- Recent results indicate that medium chain fatty acids have potent bacteriostatic capacities [3].

\subsection{Improvement of colonization resistance}

A diverse and stabile microflora can prevent the growth and attachment of pathogenic bacteria. Bacteria regarded as beneficial create a less favorable gut environment for Enterobacteriaceae [8]. Especially Lactobacillae are regarded as positive bacteria, the production of lactic acid and the bacteriocins, which are sometimes produced, suppress the growth of E. coli. Improvement of the colonization resistance can be obtained by the following measures:

- Addition of probiotics: the addition of high levels of bacteria is regarded as positive e.g. Lactobacillae, certain Streptococcus strains in the diet or drinking water [8].

- Addition of prebiotics: certain nutrients (e.g. inuline, mannan-oligo-saccharides) known to be substrates for, e.g. Lactobacillae can be added to the diet.

- Choice of feed ingredients: ileal undigested residues from certain raw materials and feed ingredients can form the substrate for the growth of beneficial bacteria, e.g. resistant starch from potato and maize origin $[17,23]$.

\subsection{Decrease the attachment of bacteria and increase immune response}

Certain additives may reduce the attachment of bacteria to enterocytes. The systemic and local immune response of animals can be influenced by certain nutrients [9].

- Antibodies in the diet: e.g. plasma proteins, egg powder, etc.

- Mannose: this sugar may block glycoproteins and consequently reduce the attachment of Enterobacters [1].

- The immune response and cellular defence can be improved by $\beta$-glucans, n-3 fatty acids, selenium, and vitamins A, D, E [9].

\section{DISCUSSION}

From a nutritional point of view, different steps in the process leading to PWS were proposed. An important factor is the inadequate development of the gut to digest the 'vegetable' diet provided after weaning. But also other steps as mentioned in Figure 1 are important. Regarding the nature of the different disturbing steps, specific measures in feed composition and feeding strategy are proposed and discussed. Some of these measures when used in diet optimization consistently show a positive effect and improve production and health in piglets post weaning, for example organic acids, antibodies and the use of well digestible raw materials. Some measures are regarded as positive but are difficult to achieve, for example increasing feed intake just before and after weaning. Many of the feed additives mentioned, for example enzymes, probiotics, nucleotides etc. have variable effects under practical conditions. Factors influencing the effectiveness of these feed additives are the nature and amount of the substrate in the diet, the effective $\mathrm{pH}$ in the 
digestive tract, housing conditions and infection pressure from the environment, etc. Still more insight and research is required for an appropriate evaluation and practical application of the measures mentioned.

\section{ACKNOWLEDGEMENT}

The European Union is greatly acknowledged for financial support of the project HEALTHYPIGUT (contract No. QLK5-CT 2000-00522). In addition the Dutch Product Board Animal Feed is acknowledged for the financial contribution. The authors are solely responsible for this text, which does not represent the opinion of the EC, and the EC is not responsible for the information delivered.

\section{REFERENCES}

[1] Allen V.M., Fernandez F., Hinton M.H., Evaluation of the influence of supplementing the diet with mannose or palm kernel meal on salmonella colonization in poultry, Brit. Poultry Sci. 38 (1997) 485-488.

[2] Bruininkx E., Individually measured feed intake characteristics in group-housed weanling pigs, $\mathrm{PhD}$ Thesis, Agricultural University of Wageningen, 2002.

[3] Decuypere J.A., Dierick N.A., The combined use of triacylglycerols containing mediumchain fatty acids and exogenous lipolytic enzymes as an alternative to in-feed antibiotics in piglets: concept, possibilities and limitations. An overview, Nutr. Res. Rev. 16 (2003) 193-209.

[4] Dirkzwager A., Veldman B., Bikker P., The effect of weaning and the addition of PHA lectins at several gut parameters in piglets, Report for the Dutch Product Board Animal Feed (In Dutch), 2003.

[5] Dirkzwager A., Elbers A.R.W., Aar P.J. van der Vos J.H., Effect of particle size and addition of sunflower hulls to diets on the occurrence of oesphagogastric lesions and performance in growing-finishing pigs, Livest. Prod. Sci. 56 (1998) 53-60.

[6] Hopwood D.E., Hampson D.J., Interactions between the intestinal microflora, diet and diarrhoea, and their influences on piglet health in the immediate post-weaning period, in: Pluske J.R., Le Dividich J., Verstegen M.W.A. (Eds.), Weaning the Pig, Wagenin- gen Academic Publishers, The Netherlands, 2003, pp. 199-218.

[7] Kelly D., Smyth J.A., McCracken K.J., Digestive development of the early weaned pig; effect of level of food intake on digestive enzyme activity during the immediate postweaning period, Brit. J. Nutr. 65 (1991) 181188.

[8] Kelly D., Probiotics in young and newborn animals, J. Anim. Feed Sci. 7 (Suppl. 1) (1998) 15-23.

[9] Klasing K.C., Nutritional modulation of resistance to infectious diseases, Poultry Sci. 77 (1998) 1119-1125.

[10] Le Dividich J., Herpin P., Effects of climatic conditions on the performance, metabolism and health status of weaned piglets: a review, Livest. Prod. Sci. 38 (1994) 79-90.

[11] Malago J.J., Koninkx J.F.J.G., Douma P.M., Dirkzwager A., Veldman A., Hendriks H.G.C.J.M., Dijk J.E. van, Differential modulation of enterocyte-like Caco-2 cells after exposure to short-chain fatty acids, Food Addit. Cont. 20 (2003) 427-437.

[12] Marion J., Biernat M., Thomas F., Savary G., Le Breton Y., Zabielski R., Le Huërou-Luron I., Le Dividich J., Small intestine growth and morphometry in piglets weaned at 7 days of age. Effects of level of energy intake, Reprod. Nutr. Dev. 42 (2002) 339-354.

[13] Nabuurs M.J.A., Etiology and pathogenic studies on post weaning diarrhea, $\mathrm{PhD}$ Thesis, State University Utrecht, 1991.

[14] Nabuurs M.J.A., Hoogendoorn A., van der Molen E.J., van Osta A.L.M., Villous height and crypt depht in weaned and unweaned pigs, reared under various circumstances in the Netherlands, Res. Vet. Sci. 55 (1993) 78-84.

[15] Nurmi E., Rantala M., New aspects of Salmonella infection in broiler production, Nature 241 (1973) 210-211.

[16] Pluske J.R., Williams I.H., Aherne F.X., Maintenance of villous height and crypt depth in piglets by providing continuous nutrition after weaning, Anim. Sci. 62 (1996) 131-144.

[17] Reid C.A., Hillman K., The effects of retrogradation and amylose/amylopectin ratio of starches on carbohydrate fermentation and microbial populations in the porcine colon, Anim. Sci. 68 (1999) 503-510.

[18] Roth F.X., Kirchgessner M., Organic acids as feed additives for young pigs: Nutritional and gastrointestinal effects, J. Anim. Feed Sci. 7 (Suppl. 1) (1998) 25-33. 
[19] Simon O. The mode of action of NSP hydrolysing enzymes in the gastrointestinal tract, J. Anim. Feed Sci. 7 (Suppl. 1) (1998) 115-123.

[20] Sissons J.W., Aetiology of diarrhoea in pigs and ruminant calves, in: Haresign W., Cole D.J.A. (Eds.), Recent Advances in Animal Nutrition, Butterworths, London, UK, 1989. pp. 261-282

[21] Smits B., Jongbloed A.W., Sebek L.B.J., Effect of pelleting and feeding level on apparent digestibility and feeding value of diets for growing-finishing pigs, Anim. Feed Sci. Techn. 45 (1994) 349-362.

[22] Stiles J.C., Sparks W., Ronzio R.A., The inhibition of Candida albicans by oregano, J. Appl. Nutr. 47 (1995) 96-102.

[23] Topping D.L., Gooden J.M., Brown I.L., Biebrick D.A., McGrath L., Trimble R.R.P., Choct M., Illman R.J., A high amylose (Amylomaize) starch raises proximal large bowel starch and increases colon length in pigs, Nutr. Metab. 127 (1996) 615-622. 